EGU2020-5815, updated on $20 \mathrm{Jul} 2020$

https://doi.org/10.5194/egusphere-egu2020-5815

EGU General Assembly 2020

(c) Author(s) 2020. This work is distributed under

the Creative Commons Attribution 4.0 License.

\title{
Unexpected thermal history of a syn-collisional basin revealed by geo- and thermochronology: the case of the Tertiary Piedmont Basin (Western Alps, Italy)
}

Chiara Amadori ${ }^{1}$, Antonio Langone ${ }^{2}$, Mattina Marini ${ }^{3}$, Reguzzi Simone ${ }^{3}$, Barbara Carrapa ${ }^{4}$, Matteo Maino ${ }^{1,2}$, and Andrea Di Giulio ${ }^{1}$

'University of Pavia, Department of Earth and Environmental Sciences, Pavia, Italy (chiara.amadori@unipv.it; matteo.maino@unipv.it, andrea.digiulio@unipv.it)

${ }^{2}$ IGG-CNR U.O.S. - Pavia, Italy (antonio.langone@unipv.it)

${ }^{3}$ University of Milan, Department of Earth Science 'A. Desio', Milan, Italy (mattia.marini@unimi.it; simone.reguzzi@unimi.it)

${ }^{4}$ University of Arizona, Geosciences Department, AZ, USA (bcarrapa@email.arizona.edu)

The Tertiary Piedmont Basin (TPB) in NW Italy represents an episutural basin developed since the Late Eocene in the retrobelt of the Western Alps and in the foreland of the Northern Apennine. During Oligo-Miocene time, up to $3 \mathrm{~km}$-thick clastic deposits filled the basin recording the tectonics associated with the shift from the Alpine collisional thickening and the progressive NE-migration of the Apennine. The continental thickening was also accompanied by the opening of the LiguroProvençal Basin and the drift of the Corsica-Sardinia block. Because of this key-position, the tectono-sedimentary and thermochronological history of the TPB has been the object of extensive investigations (Maino et al., 2013 and reference therein). However, several questions regarding its burial-exhumation history are still open. In order to define the thermal history of the source-sink system, we combined literature data with new detrital apatite fission-track analyses and zircon U$\mathrm{Pb}$ dating from Upper Priabonian to Lower Miocene syn-tectonic deposits. Results from AFT analysis show: i) a single reset population at $24.8 \pm 1.2 \mathrm{Ma}$ (Late Chattian) in the lowermost Late Priabonian sample; ii) partially annealed apatite grains from Early Rupelian sample; iii) unannealed Late Rupelian-Miocene samples with AFT age populations spanning from Late Cretaceous to Late Oligocene in time. Data from the Ligurian Alps crystalline massifs report similar AFT cooling ages between $22.9 \pm 5.3-24.0 \pm 1.4 \mathrm{Ma}$. This, combined with our data, shows that the bottom of the TPB sequence experienced $\sim 110{ }^{\circ} \mathrm{C}$ heating and subsequent cooling together with its nearby margin. The heating experienced by the basin combined with reconstructed sedimentary thickness (before the exhumation/cooling event) of ca. $<3 \mathrm{~km}$, implies an elevated geothermal gradient of about $60^{\circ} \mathrm{C} / \mathrm{Km}$, which is anomalous for a thickened orogenic crust. Furthermore, one sample from Upper Oligocene sedimentary rocks contains an AFT detrital population age (33.6 \pm 2 $\mathrm{Ma}$ ) consistent with a youngest U-Pb age peak of $33.6 \mathrm{Ma}$ from co-magmatic zircon grains, which likely reflects the age of volcanites today buried under the Po Plain (Di Giulio et al., 2001). Detrital zircon U-Pb ages show two main populations at ca. 290 and ca. $460 \mathrm{Ma}$, which are expected products of a Variscan source now exposed in the Ligurian Alps and Southern Alps. Our new geothermochronological data overall suggests a distributed Oligocene thermal signal, the origin of 
which is discussed. Possible explanations are: 1) a $>3 \mathrm{~km}$ of focused erosion associated with tectonic deformation occurred in the TPB and nearby margin and/or 2) an anomalously high heat flow event driven by asthenospheric rise as a consequence of the Liguro-Provençal rifting.

Maino M., Decarlis A., Felletti F., Seno S. (2013) Tectono-sedimentary evolution of the Tertiary Piedmont Basin (NW Italy) within the Oligo-Miocene central Mediterranean geodynamics. Tectonics, 32, 593-619.

Di Giulio, A., Carrapa B., Fantoni R., Gorla L., Valdisturlo L. (2001) Middle Eocene to Early Miocene sedimentary evolution of the western segment of the South Alpine foredeep (Italy). Int. J. Earth Sci., 90, 534-548. 